\title{
The Impact of Family Psycho-education Therapy on Family Burden in Caring for Older Adult with Dementiain Bogor
}

\author{
Livana $\mathrm{Ph}^{1}$, Yossie Susanti Eka Putri ${ }^{2}$ \\ ${ }^{1}$ Mental Nursing Department, Ners Study Program, Kendal College of Health Sciences, Kendal, Indonesia \\ ${ }^{2}$ Mental Nursing Department, Nursing Science Faculty, Indonesian University, Jakarta, Indonesia
}

Email address:

livana.ph@gmail.com (L. Ph)

\section{To cite this article:}

Livana Ph, Yossie Susanti Eka Putri. The Impact of Family Psycho-education Therapy on Family Burden in Caring for Older Adult with Dementiain Bogor. European Journal of Biophysics. Vol. 7, No. 2, 2019, pp. 46-51. doi: 10.11648/j.ejb.20190702.13

Received: June 12, 2019; Accepted: August 13, 2019; Published: October 9, 2019

\begin{abstract}
Dementia is a prevalent health problem and major cause of disability and dependency among older adults (WHO, 2012). Family, as primary support system, should be able to provide care for older adult with dementia. In provision of care, family may deal with problems which perceived as either physical or psychological problems. Family psycho-education is one of specialist nursing interventions provided for family in caring for older adult with dementia (Tang et al, Varcarolis 2014). This study aimed to identify impact of family psycho-education therapy on family burden in caring for older adult with dementia. The study design wasquasi experiment pre and post test with control group. The study population was family who provided care for older adult with dementia. Study sample consisted of 26 families of intervention group and 26 families of control group, whom selected through purposive sampling method. The intervention was conducted in 5 sessions by providing module and logbook to the families. Questionnaire of Zarit Caregiver Burden Interview was employed for data collection and independent $t$-test was applied to analyze the data with statistical significance of 0,000 . The result indicated a significant difference in family caregiving burden between the intervention and control group following the intervention. Family psychoeducation therapymay relieve family burden in caring for older adult with dementia. Psychiatric nurse specialist is encouraged to implement family psycho-education therapy which may affect family's competency in providing care for older adult with dementia.
\end{abstract}

Keywords: Family Psycho-education Therapy, Caring Burden, Older Adult with Dementia

\section{Introduction}

The number of older adult has seen a significant increase over the years. WHO (2013) stated that population of older adults would grow from $11 \%$ in 2000 to $22 \%$ by 2050 . The number is estimated to rise from 605 million into 2 billion people. United Nations claimed in 2011 that people life expectancy in 2000-2005 was 66.4 years. The figure would likely to increase into 77.6 years by $2045-2050$. [1]

Indonesia was among Asian countries with the highest population of people aged 60 years or older after China and India (Pusat Data dan Informasi Kementerian Kesehatan RI 2012). In 2010, population of older adults mounted up to 23.9 million people $(9.77 \%)$ with life expectancy of 67.4 years old. It is estimated that the population would reach 28.8 million (11.34\%) by 2020 with life expectancy of 71.1 years old. [2]
Dementia is one of common health problem and major cause of disability and dependency among older adults (WHO, 2012). Prevalence of dementia was estimated to be 35.6 million cases in 2011 and an epidemiological study expected the figure to dramatically increase by 2 folds every 20 years, which is 65.7 million by 2030 and 115.4 million by 2050. [1] Moreover, WHO established dementia as a priority health problem that requires a quick resolve. There was noofficial data from Indonesia government about the amount of population of older adults with dementia and Western Java had the highest population of older adults that occupied $7 \%$ of total population. [2] Therefore, Department of Public Health of Bogor established a program to develop an integrated health service which is based on health center. Judging 
from dementia impact toward older adults and their caregivers, it is an iceberg phenomenon that if were left untreated may result in negative impact for older adult and caregiver overall well-being.

Family as the main support system is responsible for providing care for older adult with dementia. However, in reality, family has to deal with many problems in delivery of care. Several studies revealed that caregiver perceived burden in provision of care for older adult with dementia and the burden involved both physical and psychological burden. [3] A study conducted by Putri and Riasmini (2012) on predictor of family caregiving burden and depression in caregiving for elderly with dementia in community, revealed that there were 183 older adults with dementia in Depok, $47 \%$ of families were affected by depression and perceived moderate level of burden $(55.7 \%)$ in caregiving for elderly with dementia. [4] This may lead family to depression and burden when providing care for older adult with dementiaIt is necessary to support caregivers so they would be able to enact their role properly and to manage their own health. A number of studies discovered that support had a significant impact for caregiver. [5] The significance of support provided by health professionals for family in caregiving for elderly with dementia was also reported by caregivers. [6]

Based on study results outlined above, it can be concluded that caregiver really appreciates supports provided by health care professional in caregiving for older adult with dementia; hence development of nursing care should not solely focus on older adults but also their family in enacting caregiver role in community. Family psycho-education is a nurse specialist therapy which particularly aimed for caregiver who provides care for older adult with dementia.

Family psycho-education is a family therapy provided for family of older elderly with dementia (caregiver). Its objective is to reduce intensity of emotion within family, promote family's knowledge about a disease through education on effort and behavioral manifestations which may encourage family's strength, and as a strategy of crisis management. [7]

This study employed Family Psycho-education Therapy (FPT). The therapy was proven to be effective in reducing burden and improving caregiver satisfaction in caring for elderly with dementia. [8] The therapy was expected to facilitate family in dealing with problems during provision of care, promoting their knowledge about a disease or health problem affecting the family, developing skills in caring for own self and family member, and providing support for family member.

Based on aforementioned backgrounds, authors intended to examine the effectiveness of family psycho-education theapy in reducing family burden in delivery of care for elderly with dementia. This study aimed to analyze the impact of family psycho-education in reducing family burden in caring for older adult with dementia.

\section{Material and Methods}

The study design wasquasi experiment pre and post test with control group. [9] Study population was family who provided care for elderly with dementia. The study sample comprised 26 families of intervention group and 26 families of control group. Families were selected through purposive samplingmethod with inclusion criteria were as follows: 1) Family who provided care for older adult with dementiaand lived under the same roof with him. 2) Capable of reading and writing. 3) Aged between 21-59 years. 4) Main caregiver of older adult with dementia. 5) Consented to be involved in this study as participant. The inclusion criteria of older adult with dementia were: 1) Aged 60 years or older. 2) Diagnosed with dementia (through MMSE screening). 3) Competent in reading and writing. [10]

The study was conducted in Ciwaringin for intervention group and Kebon Kelapa for control group, where both villages were target areas of Merdeka Health Center of Bogor City.

The independent variable of study was family psychoeducation therapy. The dependent variable was burden perceived by family in caregiving for elderly with dementia. Data collection employed instrument of family caregiving burden of Zarit Caregiver Burden Interview (consisted of 22 items).

Older adults were screened by using Mini Mental State Examination (MMSE). Pre-test was conducted on family of elderly with dementia in both intervention and control groups by utilizing instrument of caregiving burden prior to the intervention. Following completion of questionnaire, the intervention group was provided with family psychoeducation therapy in 3 sittings which divided into 5 sessions, while control group was provided with education about methods in caregiving for older adult with dementia. Posttest was conducted on both groups after the intervention by completing the questionnaire of caregiving burden. Following data collection, control group was later provided with family psycho-education therapy as implementation of principle of justice in research ethics.

The data were analyzed by applyingpaired t-test (caregiving burden of both groups before and after the intervention was provided) with significance level of 0.05 andindependent t-test (caregiving burden of intervention group after the intervention was provided) with significance level of 0,000 . [11]

\section{Result}

Characteristic of age and length of caregiving for elderly with dementia of both intervention and control group was numerical data which analyzed by calculating Central Tendency that included: mean, median, mode, standard deviation, minimum and maximum value. Equality of age and length of caregiving variable were determined by using regression correlation test. 
Table 1. Distribution and Analysis of Equality of Age and Length of Caregiving for Older Adults with Dementia in Bogor City ( $n=52)$.

\begin{tabular}{|c|c|c|c|c|c|c|}
\hline Variable & $\mathbf{n}$ & Mean & Median & SD & Min-Max & p value \\
\hline \multicolumn{7}{|l|}{ Age } \\
\hline Intervention group & 26 & 41,3 & 42,5 & 9,849 & $22-70$ & \\
\hline \multirow[t]{2}{*}{ Control group } & 26 & 43,4 & 41,5 & 11,395 & $16-71$ & 0,067 \\
\hline & 52 & 42,35 & 42 & 10,622 & $16-71$ & \\
\hline \multicolumn{7}{|c|}{ Length of caregiving for older adult with dementia } \\
\hline Intervention group & 26 & 3,3 & 4 & 1,185 & $0-4$ & \\
\hline \multirow[t]{2}{*}{ Control group } & 26 & 5,5 & 3,5 & 3,744 & $1-13$ & 0,083 \\
\hline & 52 & 4,4 & 3,75 & 2,465 & $0-13$ & \\
\hline
\end{tabular}

The table suggested that the average of participants' age of both groups was 42.35 years with standard deviation of 10.622 years. The youngest participant was 16 years while the oldest was 71 years. The average length of caregiving of both groups was 4.4 years with standard deviation of 2.645 years. The longest caregiving period was 13 years.

The analysis result revealedthat there was no significant correlation between age variable in both intervention and control group $(p=0,067 ; \alpha=0.05)$. Moreover, it also revealed that there was no significant correlation between length of caregiving or older adult with dementia in both intervention and control group ( $p=0,083 ; \alpha=0.05)$.

Chi square was applied to examine the relationship between participant's characteristics of sex, education, employment status, household income, type of family, familial relationship with elderly, comorbidity of family, and level of burden perceived by family in caregiving for older adult with dementia. The distribution and frequency of these variables were presented in table 2 .

The equality analysis of characteristic of sex, education, employment status, household income, type of family, familial relationship with elderly, comorbidity of family, and level of caregiving burden revealed $p$ value $>0.05$ which implied absence of significant difference between variable of sex, education, employment status, household income, type of family, familial relationship with elderly, comorbidity of family, and level of caregiving burdenin both groups.

Table 2. Distribution and Analysis of Equality of Sex, Education, Employment status, Household Income, Type of Family, Familial Relationship with Elderly, Comorbidity of Family of Older Adult with Dementia in Bogor City $(n=52)$.

\begin{tabular}{|c|c|c|c|c|c|c|c|}
\hline \multirow{2}{*}{ Variable } & \multicolumn{2}{|c|}{ Intervention group } & \multicolumn{2}{|c|}{ Control group } & \multirow{2}{*}{ Total } & \multirow{2}{*}{$\%$} & \multirow{2}{*}{ p value } \\
\hline & $\mathbf{f}$ & $\%$ & $\mathbf{f}$ & $\%$ & & & \\
\hline \multicolumn{8}{|l|}{ Sex } \\
\hline Male & 0 & 0 & 2 & 8 & 2 & 4 & \multirow{3}{*}{0,000} \\
\hline \multirow{2}{*}{ Female } & \multirow[t]{2}{*}{26} & \multirow[t]{2}{*}{100} & \multirow[t]{2}{*}{24} & \multirow[t]{2}{*}{92} & 50 & 96 & \\
\hline & & & & & 52 & 100 & \\
\hline \multicolumn{8}{|l|}{ Education } \\
\hline Primary school graduate & 7 & 27 & 11 & 42 & 18 & 35 & \multirow{6}{*}{0,341} \\
\hline Middle school graduate & 7 & 27 & 8 & 31 & 15 & 29 & \\
\hline High school graduate & 12 & 46 & 7 & 27 & 19 & 36 & \\
\hline Diploma graduate & 0 & 0 & 0 & 0 & 0 & 0 & \\
\hline \multirow{2}{*}{ Bachelor } & \multirow{2}{*}{0} & \multirow{2}{*}{0} & \multirow[t]{2}{*}{0} & \multirow[t]{2}{*}{0} & 0 & 0 & \\
\hline & & & & & 52 & 100 & \\
\hline \multicolumn{8}{|l|}{ Employment status } \\
\hline Unemployed & 19 & 73 & 17 & 65 & 36 & 69 & \multirow{3}{*}{0,117} \\
\hline \multirow[t]{2}{*}{ Employed } & \multirow[t]{2}{*}{7} & \multirow[t]{2}{*}{27} & \multirow[t]{2}{*}{9} & \multirow[t]{2}{*}{35} & 16 & 31 & \\
\hline & & & & & 52 & 100 & \\
\hline \multicolumn{8}{|l|}{ Household income } \\
\hline $\begin{array}{l}<\text { Regional Minimum Wage in } \\
\text { Bogor }(\operatorname{Rp} 2.250 .000)\end{array}$ & 7 & 27 & 8 & 31 & 15 & 29 & \multirow{4}{*}{0,083} \\
\hline $\begin{array}{l}\text { > Regional Minimum Wage in Bogor } \\
\text { (Rp2.250.000) }\end{array}$ & 0 & 0 & 0 & 0 & 0 & 0 & \\
\hline No income & 19 & 73 & 18 & 69 & 37 & 71 & \\
\hline & & & & & 52 & 100 & \\
\hline Type of family & & & & & & & \\
\hline Nuclear family & 3 & 12 & 5 & 19 & 8 & 15 & \\
\hline Extended family & 23 & 88 & 21 & 81 & 44 & 85 & 1 \\
\hline & & & & & 52 & 100 & \\
\hline Familial relationship with the older a & & & & & & & \\
\hline Spouse & 3 & 12 & 1 & 4 & 4 & 8 & \\
\hline Mother/Father in law & 1 & 4 & 2 & 8 & 3 & 6 & \\
\hline Child & 20 & 76 & 22 & 84 & 42 & 80 & 0,43 \\
\hline Grandchild & 2 & 8 & 1 & 4 & 3 & 6 & \\
\hline & & & & & 52 & 100 & \\
\hline Family comorbidity & 16 & 60 & 2 & 80 & 37 & 70 & 0,27 \\
\hline
\end{tabular}




\begin{tabular}{|c|c|c|c|c|c|c|c|}
\hline \multirow{2}{*}{ Variable } & \multicolumn{2}{|c|}{ Intervention group } & \multicolumn{2}{|c|}{ Control group } & \multirow{2}{*}{ Total } & \multirow{2}{*}{$\%$} & \multirow{2}{*}{ p value } \\
\hline & f & $\%$ & f & $\%$ & & & \\
\hline Diabetes mellitus & 1 & 4 & 0 & 0 & 1 & 2 & \\
\hline Hypertension & 5 & 20 & 1 & 4 & 6 & 12 & \\
\hline Stroke & 1 & 4 & 0 & 0 & 1 & 2 & \\
\hline \multirow[t]{2}{*}{ Gastritis } & 3 & 12 & 4 & 16 & 7 & 14 & \\
\hline & & & & & 52 & 100 & \\
\hline
\end{tabular}

The table 3 revealed that $35 \%$ of participants of intervention group perceived severe level of burden in providing care for elderly with dementia before the intervention. However, after family psycho-education therapy was provided, $73 \%$ of them perceived only a mild level of burden. The analysis result implied a significant difference in level of burden perceived by family in caregiving for older adult with dementia prior to and following the intervention $(p=0,000 ; \alpha=0.05)$.

The table suggested that $57.5 \%$ of families of control group perceived moderate level of burden in providing care for older adult with dementia before the intervention was provided. However, after the therapy was provided, $50 \%$ of them still perceived moderate level of burden in caregiving for older adult with dementia. The result indicated that there was no significant difference in level of burden perceived by family of control group in caregiving for older adult with dementia before and after the education about caregiving methods was provided ( $p=0,08 ; \alpha=0.05$ ).

The difference in level of burden perceived by family of both groups in providing care for elderly with dementia before and after the intervention was presented in table 4 .

Table 3. Difference in Burden Perceived by Family in Caregiving for Older Adult with Dementia of Both Intervention and Control Groups Before and After the Intervention $(n=26)$.

\begin{tabular}{|c|c|c|c|c|c|c|c|}
\hline \multirow{3}{*}{ Group } & \multicolumn{3}{|l|}{ Pre-Intervention } & \multicolumn{3}{|l|}{ Post-Intervention } & \multirow{3}{*}{ p value } \\
\hline & \multirow{2}{*}{ Caregiving burden } & \multicolumn{2}{|c|}{ Total } & \multirow{2}{*}{ Caregiving burden } & \multicolumn{2}{|c|}{ Total } & \\
\hline & & f & $\%$ & & f & $\%$ & \\
\hline \multirow{3}{*}{ Intervention group } & Mild & 2 & 7,5 & Mild & 19 & 73 & \multirow{3}{*}{0,000} \\
\hline & Severe & 9 & 35 & Severe & 1 & 4 & \\
\hline & Total & 26 & 100 & Total & 26 & 100 & \\
\hline \multirow{3}{*}{ Control group } & Mild & 7 & 27 & Mild & 9 & 34,6 & \multirow{3}{*}{0,008} \\
\hline & Severe & 4 & 15,5 & Severe & 3 & 11,5 & \\
\hline & Total & 26 & 100 & Total & 26 & 100 & \\
\hline
\end{tabular}

Table 4. Difference in Level of Burden Perceived by Family of Both Groups in Providing Care for Older Adult with Dementia after the Intervention $(n=$ 26).

\begin{tabular}{lllll}
\hline \multirow{3}{*}{ Group } & \multicolumn{3}{l}{ After the Intervention } & \\
\cline { 2 - 4 } & Caregiving & Total & \\
\cline { 2 - 4 } Burden & Mild & 19 & $\mathbf{n}$ & \\
\hline \multirow{3}{*}{ Intervention group } & Moderate & 6 & 23 & \\
& Severe & 1 & 4 & \\
& Total & 26 & 100 & \multirow{2}{*}{0,269} \\
& Mild & 10 & 38,5 & \\
Control group & Moderate & 13 & 50 & \\
& Severe & 3 & 11,5 & \\
& Total & 26 & 100 & \\
\hline
\end{tabular}

$\mathrm{T}$ value was based on assumption that all variants were equal. T-test analysis revealed $t$ value of 0,269 (significance level: 0,000). It indicated that null hypothesis was rejected and implied a significant change in level of burden perceived by family in both intervention and control group after the intervention.

\section{Discussion}

The findings demonstrated that majority of families in intervention group perceived a moderate level of burden in caregiving $(57.5 \%)$ before the intervention were performed, while $35 \%$ of them perceived severe level of burden and mild level $7.5 \%$. Following the intervention, most of participants perceived mild level of caregiving burden (73\%); hence, the analysis result indicated that family psycho-education therapy was able to lower burden perceived by family in caregiving for elderly up to $65.4 \%$. Statistical analysis revealed $\mathrm{p}$ value of 0.000 which implied a significant difference in caregiving burden of intervention group before and after the therapy was provided.

This result supported the hypothesis which stated that there is a significant change in family caregiving burden before and after the implementation of family psycho-education. It also coincided with a study conducted by Putri and Riasmini (2012) on predictor of family caregiving burden and depression in providing care for older adult with dementia in Depok. [6] The study suggested that $47 \%$ of families were affected by depression and perceived moderate level of burden $(55.7 \%)$ in caregiving for older adult with dementia. The figure was quite similar with pre-intervention family caregiving burden in this study. This result also concurred with previous study which revealed that burden perceived by family caregiver of elderly with dementia might be resulted from depression and strain in caregiving. $[5,7,12]$ Based on those study results, authors assumed it would be necessary to provide nursing intervention for family of older adult with dementia to reduce the caregiving burden so they may enact 
their caregiving role properly as well as maintaining their health. $[13,14]$

Nursing intervention provided in this study was family psycho-education therapy. This therapy may be performed on family of older adult with dementia (caregiver). The main objective of this therapy is to lower intensity of emotion within family, promote family's knowledge about a disease through education on effort and behavioral manifestations which may encourage family's strength, and as a strategy of crisis management. $[7,15]$ The therapy was provided in 5 sessions within 4 sittings. The effect of therapy in intervention group would then be compared with control group. The finding showed that there was significant difference as much as $65.4 \%$ after the therapy was provided. It conformed to Elmstahl et al's study (2012) which stated that Family Psycho-education therapy was proven to be effective in decreasing burden, improving family satisfaction in caring for elderly, and promoting family's knowledge about a disease or health problem. [8, 16-18] Based on the results and previous studies, author concluded that it would be crucial to provide intervention for family who provides care for older adult with dementia; thus, development of nursing care should not solely emphasize on older adults but also their family in performing caregiver role in community.

The result revealed that majority of participants in control group perceived moderate level of caregiving burden before the intervention (57.5\%) and it slightly changed into $50 \%$ following the intervention. It indicated that intervention of health education provided for control group was only able to lower the caregiving burden around $7.5 \%$ which necessitated another nursing intervention such as family psycho-education which was evidenced to be effectivefor reducing caregiving burden as much as $65.4 \%$ in intervention group. [17-19].

The analysis revealed that majority of participants in intervention group perceived mild level of burden after the therapy $(73 \%)$, while half of participants in control group perceived moderate level of burden $(50 \%)$. The $t$ value was 0,269 (t-value $>0,000$ ). Therefore, it could be concluded that there was significant difference in level of burden perceived by family in both control and intervention group after the therapy was provided.

There was difference in burden perceived by family who provided care for elderly with dementia in both control and intervention group after the therapy was provided. The findings also showed that there were 19 participants in intervention group who perceived mild level of caregiving burden, while there were only 10 participants in control group who perceived mild level of caregiving burden. It also implied that intervention group had greater number of participant who perceived mild level of burden (9 participants greater, $34.6 \%$ ), fewer participants who perceived moderate level of burden (7 participants fewer, $26.9 \%$ ), and fewer participants who perceived severe level of burden ( 2 participants fewer, $7.8 \%$ ) than control group. This also indicated that family psycho-education therapy was able to alleviate caregiver burden as much as $65.4 \%$ between intervention and control group. [20]
This study result coincided with a study conducted byLiu, et al (2012) which claimed that psycho-education was able to improve family support in providing care for a family member afflicted by illness. [21] Another study revealed that psycho-education was able to improve family's competency in caregiving for a family member who was affected by disease (Kustiawan, 2012). Based on these statements, author concluded that psycho-education therapy was able to relieve caregiving burden of family in intervention group in comparison to control group whom were not provided with family psycho-education therapy.

\section{Conclusion}

It can be concluded that there was a significant change in caregiving burden of family in intervention group prior to and following the implementation of family psychoeducation, while control group did not demonstrate any significant change in the same matter. Bivariate analysis suggested that there was significant difference in caregiving burden of family in intervention group than in control group after the intervention was provided.

The study result proved that family psycho-education therapy was effective for reducing family caregiving burden. It is recommended for psychiatric nurse specialist to implement family psycho-education therapy which may affect family's competency in providing care for older adult with dementia.

\section{References}

[1] Organization, W. H., Fact sheet No. 362, Dementia. 2013.

[2] Badan Pusat Statistik, B. K. d. K. B. N. and K. Kesehatan., Survei Demografi dan Kesehatan Indonesia 2012.. 2012: Jakarta.

[3] Puspitasari, S., Gambaran Beban Caregiver Keluarga pada Pasien Kanker di Rumah Singgah Yayasan Kanker (Bachelor's thesis,, in Fakultas Kedokteran dan Ilmu Kesehatan. 2017, UIN Syarif Hidayatullah Jakarta: Jakarta.

[4] Putri Y, R., Prediktor Beban merawat Dan Depresi Caregiver Dalam Merawat.

[5] lanjut Usia Dengan Demensia Di Masyarakat., in Fakultas Ilmu Keperawatan. 2013, Universitas Indonesia: Depok.

[6] Lee, J. V., Bakker, T. J. E. M dan Duivenvoorden, H. J Multivariate models of subjective caregiver burden in dementia: A systematic review. Ageing Research Reviews, 2014. 15: p. 76-93.

[7] Putri, Y. S. E., \& Riasmini, N. M, The Predictors of Caregiver's Burden and Depression Level in Caring Elderly People with Dementia at Community. Jurnal Ners, 2017.8 (1): p. 88-97.

[8] Tang. B, H., E, Kurzman. R, Mould-Quevedo. J. F, Pan. S, Yang. J dan Qiao. J Clinical characterization and the caregiver burden of dementia in China. Value in Health Regional Issues, 2013. 2: p. 118-126. 
[9] Andren, S., dan Elmstahl, S, A view of cross boundary relationships. Psychosocial intervention for family caregivers of people with dementia reduce caregiver's burden: Development and effect after 6 and 12 months. Scandinavian Journal of Caring Sciences, 2008. 22: p. 98-109.

[10] Polit, D. F., Beck, C. T, Nursing Research Methodology (9th Edition). 2012, Philadelphia: Lippincott williams \& Wilkins.

[11] Polit, D. f., \& Hunger, B. P, Nursing research: principles methods (6th Edition). 2005, Philadelphia: Lippincott williams $\&$ Wilkins.

[12] Hartono, S. S., L, Statistik kesehatan. 2010, Jakarta: Rajawali Pres.

[13] Taemeeyapradit, U., Udimittipong, D dan Assanangkornchai, $\mathrm{S}$, Development of a burden scale for caregivers of dementia patients. Asian Journal of Psychiatry, 2013. 8: p. 22-25.

[14] Erfandi, Pengetahuan dan faktor-faktor yang mempengaruhi pendidikan kesehatan. 2009, Jakarta: Workpress.

[15] Friedman, M. M., Keperawatan Keluarga: teori dan praktik (family nursing: theory and practice). 2010, Jakarta: EGC.

[16] Renata, K., No body Can Help Me... I am Living Through it Alone': Experiences of Caring for People Diagnosed with
Mental Illness in Ethno-Cultural and Linguistic Minority Communities. Journal of Immigrant and Minority Health, 2006. 8 (2): p. 35.

[17] Adams, K. B., Specific effects of caring for a spouse with dementia: differences in depressive symptoms between caregiver and non-caregiver spouses. International Psychogeriatrics, 2008. 20 (3): p. 20.

[18] Hamid, A. Y. S., Buku ajar riset keperawatan konsep, etika, \& instrumentasi. 2008, Jakarta: EGC.

[19] Hooley, C., dan Mast, B, The impact of anticipatory grief of caregiver burden in dementia caregivers. The Gerontologist, 2009. 49 (43): p. 388-396.

[20] O'Grady, C. P., Stigma as experienced by family members of people with severe mental illness: The impact of participation in self-help/ mutual aid support groups. 2004, University of Toronto Canada: Canada.

[21] Sarafino, E. P. S., T. W, Health Psychology: Biopsychosocial Interactions. 7th Edition. 2012, New York: Wiley.

[22] Liu, J., Wang. L, Tan. J. P, Gauthier, S dan Zhang. Y. I, Burden, anxiety and depression in caregivers of veterans with dementia in Beijing. Archives of Gerontology and Geriatrics., 2012. 55: p. 560-563. 